\title{
Quality Analysis on the Engineering Master of Biotechnology Specialty from Enterprise
}

\author{
Xinglin Li, Yang Han, Aijie Cao, Jun Zhao, Liming Zhang, Shuli Man, Wenyuan Gao \\ Key Laboratory of Industrial Microbiology, Ministry of Education, Tianjin University of Science and \\ Technology, Tianjin, China \\ Email: lxlszf@tust.edu.cn
}

Received 2012

\begin{abstract}
In order to express the engineering master's culture status of biotechnology from some enterprises, by questionnaire, 27 engineering masters from some enterprises and 22 academic masters from two universities, were investigated on the graduate students' origin, their tutors' title, the enterprise size and classify, their dissertation theme emphasis and classify, and the experiment condition for their dissertations. The results indicated that, the engineering masters were better than the academic masters on the practice condition and the practice chances, whereas, the academic masters markedly excelled the engineering masters on the tutors' level, the test condition, and the innovation environment of science and technology.
\end{abstract}

Keywords: Engineering Master; Enterprise Culture; Biotechnology Specialty; Comparison

\section{Introduction}

Since 1984, the engineering master culture has performed for over 20 years, many engineering masters are cultured into the practical talents of engineering[1-3]. The engineering masters' culture is a type of all graduate students' education as the academic masters, but the former emphasize particularly on culturing the practical and composite talents for some enterprises $[1,4-6]$, therefore, comparison with the academic masters, it is very different at the students' types, culturing approach, and knowledge frame [7, 8]. But there are many questions during culturing of the engineering masters, they mainly are shown that, its' culturing approach lacks diversity, the culture object isn't clear, moreover, the teaching teams of the tutors from some enterprises need to be enhanced, and so on [6, 8-10].

Biotechnology, an engineering master specialty, is bringing into very important role at food, medicine, and so on. But its' engineering master culture status from the enterprises was scarcely reported. So this paper arm is to try to research the fact by questionnaire.

\section{Investigation Methods}

By questionnaire, 27 engineering masters from some enterprises and 22 academic masters from Tianjin University of Science and Technology and Tianjin University of Commerce, were investigated on the graduate students' origin, their tutors' title, the enterprise size and classify, their dissertation theme emphasis and classify, and the experiment condition for their dissertations. The engineering masters study on the biotechnology specialty at the enterprises, while the academic masters mainly study on ferment engineering specialty.

\section{Results and Discussion}

\section{The Graduate Students' Origin and Their Tutors' Title}

There were difference between the engineering masters and the academic masters at the graduate students' origin (Table 1). The in-service staffs and the equal educational background students of the engineer masters were more than those of the academic masters.

The educational background and the positional title of the research supervisors were listed in Table 2 . The research supervisors from the schools excelled the research supervisors from the enterprises on the educational background and the positional title, so the latter should be improved.

Table 1.

The graduate students' origin.

\begin{tabular}{ccccc}
\hline & $\begin{array}{c}\text { Fresh } \\
\text { graduates }\end{array}$ & $\begin{array}{c}\text { Former } \\
\text { year's } \\
\text { graduates }\end{array}$ & $\begin{array}{c}\text { Equal educational } \\
\text { background } \\
\text { students }\end{array}$ & $\begin{array}{c}\text { In-service } \\
\text { staffs }\end{array}$ \\
\hline $\begin{array}{c}\text { Engineering } \\
\text { masters }\end{array}$ & $59.3 \%$ & $18.5 \%$ & $22.2 \%$ & $18.2 \%$ \\
$\begin{array}{c}\text { Non-engineering } \\
\text { masters }\end{array}$ & $77.3 \%$ & $22.7 \%$ & $0 \%$ & $0 \%$ \\
\hline
\end{tabular}

Table 2.

The educational background and the positional title of the research supervisors.

\begin{tabular}{cccc}
\hline $\begin{array}{c}\text { Educational } \\
\text { background }\end{array}$ & $\begin{array}{c}\text { College } \\
\text { diploma }\end{array}$ & $\begin{array}{c}\text { University } \\
\text { diploma }\end{array}$ & $\begin{array}{c}\text { Postgraduate } \\
\text { diploma }\end{array}$ \\
\hline $\begin{array}{c}\text { Research supervisors } \\
\text { from the enterprise }\end{array}$ & $18.5 \%$ & $66.7 \%$ & $14.8 \%$ \\
$\begin{array}{c}\text { Research supervisors } \\
\text { from the university }\end{array}$ & $0 \%$ & $9.1 \%$ & $90.1 \%$ \\
$\begin{array}{c}\text { Positional title } \\
\text { Research supervisors } \\
\text { from the enterprise }\end{array}$ & Junior & Intermediate & Senior \\
$\begin{array}{c}\text { Research supervisors } \\
\text { from the university }\end{array}$ & $0 \%$ & $29.6 \%$ & $59.3 \%$ \\
\hline
\end{tabular}




\section{The Enterprise Size and Classify}

The investigation from the enterprise size and the enterprise classify was shown at Table 3. Many enterprises were of moderate size, and most of them were pharmacy and food corporations. On technique level, many enterprises were denominated at High and New Tech. Corporation, but the enterprises of possessing postdoctoral scientific research workstation were only $18.5 \%$.

\section{The Dissertation Theme Emphasis and Classify}

The dissertation theme emphasis and classify were listed at Tables 4 and 5. The dissertation theme from the engineering masters focused on the research of middle reaches (such as technology optimization) and the research of down stream (such as component purification), whereas the dissertation theme from the academic masters focused on the research of up stream (such as screening gene engineering culture) and the research of middle reaches. The dissertation from the engineering masters mainly reflected technology breakthrough and researches, whereas the dissertation theme from the academic masters mainly reflected application foundation researches.

\section{The Experiment Skills as Needed for the Students}

The experiment skill as needed for the masters was divided into five types by biotechnology specialty: asepsis operation, cell culture, component determining, nucleic acid analysis and protein analysis (Table 6). Two types of the masters mostly needed to grasp the experiment skill of asepsis operation, cell culture and component determining, otherwise, the academic masters must grasp the experiment skill of nucleic acid analysis and protein analysis.

\section{The Equipment Condition for Students}

The main equipments and the experiment condition evaluation were listed in Table 7 and Table 8. By their research project, the experiment condition must meet the masters to grasp the skill on asepsis operation, cell culture, component determining, nucleic acid analysis and protein analysis for accomplishing tests. Table 7 showed that the enterprises were markedly inferior to the universities.
Table 3.

The enterprise size and classify.

\begin{tabular}{|c|c|c|c|c|}
\hline \multirow{2}{*}{$\begin{array}{c}\text { Enterprise } \\
\text { size }\end{array}$} & $1-10$ person & $11-50$ person & 50-100 person & Over 100 person \\
\hline & $22.2 \%$ & $40.7 \%$ & $18.5 \%$ & $18.5 \%$ \\
\hline \multirow{2}{*}{$\begin{array}{c}\text { Enterprise } \\
\text { classify } 1\end{array}$} & Pharmacy & Food & $\begin{array}{c}\text { Research and } \\
\text { exploitation }\end{array}$ & Others \\
\hline & $40.7 \%$ & $25.9 \%$ & $14.8 \%$ & $18.5 \%$ \\
\hline \multirow[t]{2}{*}{$\begin{array}{c}\text { Enterprise } \\
\text { classify } 2\end{array}$} & $\begin{array}{l}\text { High and } \\
\text { New Tech. } \\
\text { Corporation }\end{array}$ & $\begin{array}{l}\text { Non-High and } \\
\text { New Tech } \\
\text { Corporation }\end{array}$ & $\begin{array}{l}\text { Possessing } \\
\text { postdoctoral } \\
\text { scientific } \\
\text { research } \\
\text { workstation }\end{array}$ & $\begin{array}{c}\text { Non-possessing } \\
\text { postdoctoral } \\
\text { scientific } \\
\text { research } \\
\text { workstation }\end{array}$ \\
\hline & $88.9 \%$ & $11.1 \%$ & $18.5 \%$ & $81.5 \%$ \\
\hline
\end{tabular}

Table 4.

The dissertation theme emphasis.

\begin{tabular}{ccccc}
\hline & $\begin{array}{c}\text { Research of } \\
\text { up stream }\end{array}$ & $\begin{array}{c}\text { Research of } \\
\text { middle reaches }\end{array}$ & $\begin{array}{c}\text { Research of } \\
\text { down stream }\end{array}$ & Others \\
\hline $\begin{array}{c}\text { Engineering } \\
\text { masters }\end{array}$ & $14.8 \%$ & $63.0 \%$ & $51.9 \%$ & $11.1 \%$ \\
$\begin{array}{c}\text { Academic } \\
\text { masters }\end{array}$ & $54.5 \%$ & $59.1 \%$ & $31.8 \%$ & $0 \%$ \\
\hline
\end{tabular}

Table 5.

The dissertation classify.

\begin{tabular}{ccccc}
\hline & $\begin{array}{c}\text { Application } \\
\text { foundation }\end{array}$ & $\begin{array}{c}\text { Technology } \\
\text { breakthrough } \\
\text { and research }\end{array}$ & $\begin{array}{c}\text { Industry or } \\
\text { technology } \\
\text { design }\end{array}$ & $\begin{array}{c}\text { Layout or } \\
\text { management }\end{array}$ \\
\hline $\begin{array}{c}\text { Engineer-ing } \\
\text { masters } \\
\text { Academic } \\
\text { masters }\end{array}$ & $7.4 \%$ & $66.7 \%$ & $22.2 \%$ & $3.7 \%$ \\
\hline
\end{tabular}

Table 6.

The experiment skills as needed.

\begin{tabular}{cccccc}
\hline & $\begin{array}{c}\text { Asepsis } \\
\text { operation }\end{array}$ & $\begin{array}{c}\text { Cell } \\
\text { culture }\end{array}$ & $\begin{array}{c}\text { Component } \\
\text { Determining }\end{array}$ & $\begin{array}{c}\text { Nucleic acid } \\
\text { analysis }\end{array}$ & $\begin{array}{c}\text { Protein } \\
\text { analysis }\end{array}$ \\
\hline $\begin{array}{c}\text { Engineering } \\
\text { masters }\end{array}$ & $85.1 \%$ & $95.6 \%$ & $100 \%$ & $14.8 \%$ & $40.7 \%$ \\
$\begin{array}{c}\text { Academic } \\
\text { masters }\end{array}$ & $100 \%$ & $100 \%$ & $100 \%$ & $81.8 \%$ & $77.3 \%$ \\
\hline
\end{tabular}

Table 7.

The main equipments used as accomplishing tests.

\begin{tabular}{|c|c|c|c|c|c|}
\hline & & Asepsis operation & Cell culture & Component Determineng & Nucleic acid or protein analysis \\
\hline \multirow{2}{*}{$\begin{array}{l}\text { Engineering } \\
\text { masters }\end{array}$} & Number of person & $66.7 \%$ & $59.3 \%$ & $88.9 \%$ & $48.1 \%$ \\
\hline & $\begin{array}{l}\text { Equipment } \\
\text { in common use }\end{array}$ & $\begin{array}{c}\text { Sterilizeng retort, } \\
\text { Asepsis operation desk }\end{array}$ & $\begin{array}{l}\text { Fermentation equipment, } \\
\text { oscillator }\end{array}$ & Photometer, chromatogram & $\begin{array}{l}\text { PCR apparatus, } \\
\text { electrophoresis equipment }\end{array}$ \\
\hline \multirow{2}{*}{$\begin{array}{l}\text { Academic } \\
\text { masters }\end{array}$} & Number of person & $100 \%$ & $100 \%$ & $100 \%$ & $72.7 \%$ \\
\hline & $\begin{array}{l}\text { Equipment } \\
\text { in common use }\end{array}$ & $\begin{array}{c}\text { sterilizing retort, } \\
\text { Asepsis operation desk }\end{array}$ & $\begin{array}{c}\text { Oscillator, } \\
\text { Fermentation equipment }\end{array}$ & Photometer, chromatogram & $\begin{array}{c}\text { PCR apparatus, } \\
\text { electrophoresis equipment }\end{array}$ \\
\hline
\end{tabular}

Table 8.

The experiment condition evaluation at the institutes.

\begin{tabular}{cccc}
\hline & $\begin{array}{c}\text { Number of person accomplishing } \\
\text { all tests at an enterprises }\end{array}$ & $\begin{array}{c}\text { Number of person accomplishing } \\
\text { all tests at two or more institutions }\end{array}$ & $\begin{array}{c}\text { Number of person accomplishing } \\
\text { all tests at a school }\end{array}$ \\
\hline Engineering masters & $59.3 \%$ & $37.0 \%$ & $3.7 \%$ \\
Academic masters & $0 \%$ & $27.3 \%$ & $72.7 \%$ \\
\hline
\end{tabular}


Table 9.

The masters' experiment time for their dissertation.

\begin{tabular}{|c|c|c|c|c|}
\hline Experiment time per day/hours & Under 5 & $5-7$ & 7-9 & Over 9 \\
\hline Engineering masters & $7.4 \%$ & $3.7 \%$ & $70.4 \%$ & $18.5 \%$ \\
\hline Academic masters & $31.8 \%$ & $40.9 \%$ & $27.3 \%$ & $0 \%$ \\
\hline All experiment time of performing the dissertation /Months & Under 12 & 12-18 & 18-24 & Over 24 \\
\hline Engineering masters & $3.7 \%$ & $14.8 \%$ & $55.6 \%$ & $25.9 \%$ \\
\hline Academic masters & $18.2 \%$ & $40.9 \%$ & $36.4 \%$ & $4.5 \%$ \\
\hline
\end{tabular}

\section{The Masters' Experiment Time for Their Dissertation}

The masters' experiment time for their dissertation was divided into work time per day and all experiment time of performing the dissertation (shown as Table 9). The time the engineering masters sparing were markedly longer than that of the academic masters.

\section{Conclusion}

There are very different between the engineering masters and the academic masters on the practice condition and the practice chances, the former are better than the latter, whereas, the academic masters markedly excelled the engineering masters on the tutors' level, the test condition, and the innovation environment of science and technology.

\section{REFERENCES}

Zheng L H., Yuan J B, Xiang L J, Deng J, “The consideration of the instruction to the command-based master of engineering's dissertation,” Journal of Higher Education Research, vol. 33(2), pp. 44-46, 2010.

Wu Z L, Fang Z Y, "Main problems and countermeasures in the education of engineering master," Journal of Chongqing University ( So- cial Sciences Edition), vol. 7 (2), pp.110-111, 2001.

Xia T J, Du Z H, Wu S H, Xie Y S, "On the cultivation quality of the master of engineering: problems and countermeasures," Advanced Engineering Education Research, vol. 1, pp.143-148, 2009.

Zhang W H, Wang D, Lv L, "Double tutors construct on the engineering masters,” Western China Science and Technology, vol. 11(2), pp.78-80. 2012.

Huang Q P, "Research on influencing factors and solving approaches to quality of project master's dissertations," Journal of Technology College Education, vol. 27(4), pp.72-74, 2008.

Shi P, "On systems analysis of the topic of the engineering master's dissertations," Journal of Northwestern polytechnical University (Social Sciences Edition), vol.22 (4), pp.80-83, 2002.

Zhang L L, Luo Y C, Sun Y D, "Quality assurance strategy for theses by full time master of engineering students," Journal of Graduate Education, vol. 3, pp.73-76, 2011.

Sun Y, "Quality of theses: key to the training of masters of engineering," Journal of Shandong Education College, vol. 5, pp. 82-84, 2007.

Wang D H, Liu D, Zheng X L, He D Z, Fang Z Y, “An empirical research on training models of master of engineering," Journal of Chongqing University(Social Science Edition), vol. 13(5), pp.31-34, 2007.

Lv M H, Xu W M, Yao S J, "Student origin, persons qualified to tutor and the dissertation's topic," Advanced Engineering Education Research, vol. 4, pp.71-74, 2004. 